\title{
The Prospects and Challenges of Adopting Servant-Leadership Philosophy in a Tanzania Public Leadership Context
}

\author{
Saneslaus Boniface Chandaruba \\ PhD Candidate, Department of Political Science and Public Administration \\ The Open University of Tanzania (OUT) \\ P.O. Box 23409, Dar es Salaam, Tanzania \\ E-mail: bonnychandaruba74@gmail.com
}

Received: Jan. 29, 2019 Accepted: Feb. 26, 2019 Online published: Mar. 12, 2019

doi:10.5296/jpag.v9i1.14484

URL: https://doi.org/10.5296/jpag.v9i1.14484

\begin{abstract}
The main objective of the study was to assess the prospects and challenges of adopting Servant Leadership Philosophy (SLP) in a Tanzania public leadership context. A total of 278 respondents; 109 Members of Parliament (MPs), 90 Respondents from the General Public (RGPs) and 79 key informants selected from different constituencies and localities across the country using a non-probability approach of snowball sampling were involved. Both qualitative and quantitative methods of data collection and analysis were employed. The primary and secondary data were collected through questionnaires, interviews, observations and documentary review. The key findings revealed that there are many prospects in adopting the principles of SLP in addressing public leadership deficiencies and there are several challenges to be encountered in the due process of adopting this philosophy. Thus, the study recommends, among other things, enhancing the Public Leaders Code of Ethics Act of 1995 and other established ideals for public leaders in Tanzania by adopting the principles of SLP; training public leaders on SLP and including SLP in school curricula topics with a view of grooming patriotic and ethical leaders of the next generation.
\end{abstract}

Keywords: servant-leadership, Tanzania, public leadership

\section{Introduction}

Public leadership is a social contract between public leaders and the community they serve which compels them to uphold the general will of that community; and it also binds them for their actions and decisions (Rousseau, 1762). As a discipline, public leadership has been over 
the years, receiving more intellectual attention accross the world associated with a mushrooming of contemporary theories and models to explain its nature and the way it has been evolving to meet the ever-changing needs of the human being.

One of the major public leadership challenges across the global today is about how to restrain public leaders' personal interests against the common interest of the people they lead. Dewey (1922) contends that the nature of this challenge stems from the instinct nature of the human being himself of being selfish and that it has been there for centuries. It is insisted by Dewey (1922) that all public leadership flaws including; embezzlement, unilateral decision making and other maladministrative evils are consequences of the natural behavior of the human being. Dewey supports the views of Hobbes (1651) insisting that man in his nature regardless of his place of domicile, education and culture is selfish and greedy; and if left uncontrolled tend to fight, rob and oppress one another.

Barker (1906) also argues that unless a checks and balances mechanism is properly set and instituted, the probability of a man who is a public leader to become selfish, greedy and tyrant is very high and possibly inevitable. Both Barker (1906) and Dewey (1922) agree with the views of Hobbes (1651) on the premises that it is not easy for a public leader who is uncontrolled to serve the public without being biased to his personal interests first especially when such leader has got superior powers. Therefore, the issue of conflict of interest to public leaders as emphasized by Kaufman (2008) should be an agendum to be addressed properly in the ethical public service settings if Tanzania really needs to enhance the quality of public leadership in its public service. This is because the current legal framework of the Tanzania public service as argued by Laviga (2004), Gasarasi (2004) and Tenga (2010) has not yet properly managed to curb the conflict of interest among public leaders.

\section{Literature Review}

Public service, in the context of Tanzania, is explicitly defined under the Public Service Act, Cap. 298 and Regulation No. 52 of the Standing Orders for the Tanzania Public Service of 2009 as the system or organization entrusted with the responsibility of overseeing the provision or directly providing the general public with what they need from their government or any other institution on behalf of the government as permissible by laws including the executive agencies. In the context of this study, public service means all ministries, government departments and agencies; and parastatal organizations that are used by the government to serve or provide the community with essential social services such as health care, electricity, education and water on behalf of the government.

The term servant is defined as "one who is under obligation to work for the benefit of a superior and to obey his or her commands" (Oxford English Dictionary, 1971, p.1643). Thus, according to Sendjaya and Sarros (2002), a servant leader is a person who has an innate desire to serve and strives to meet the highest priorities of others. The original term servant leader is often accredited to Christianity and the biblical teachings of Jesus where He gives instruction on the qualities of a leader, the role of the leader and the issue of power or authority of a leader (The New International Version Bible, 1986). The term philosophy is defined as "a system in which the ontology, epistemology and axiology informs and impacts 
ones view of the world" (Ruona and Lynham, 2004, p.152). Servant leadership philosophy therefore is concerned with the entire system in which a leader engages with a follower through the desire and process of serving in such a way that the leader and follower raise one another to a higher level of morality and motivation.

Spears (1996) looks at SLP as a new perspective of leadership which emphasizes on increased service to others; a holistic approach to work; promoting a sense of community; and the sharing of power in a decision-making process. Greenleaf (1977) the founder of the philosophy defines a servant-leader as a person who is seriously committed and devoted to being a servant first with an inner feeling to serve others. Greenleaf's definition assumes that a person becomes a leader not because he or she wants to earn or gain individual interest; but it is because, first as an individual he has the desire and devotedness of serving others and second, he has been entrusted by others to serve on their behalf. In the context of this study, a servant leader is defined as a patriotic public leader who is seriously devoted and committed with inner-feelings to serve the public; who can inculcate a spirit of holistic approach to work; promoting a sense of community and always puts the public interest first in the due process of discharging his or her duties and responsibilities.

\subsection{Servant Leadership Theory}

The theory of servant leadership was derived from an analogical or interpretive reasoning in which Greenleaf essentially used a metaphorical character (identified as a servant leader) and demonstrated leadership aligning with his own values, beliefs, and knowledge (Kneller, 1997). The theory is a two-fold concern of which Greenleaf (1970) brings about two fundamental assumptions. The first assumption is that individuals who want to tackle problems of the world do so intellectually; and the second one is that individuals who want to serve often miss the opportunity. According to Greenleaf (1970), there are many problems in the world that need to be tackled by intellectuals but unfortunately only a few of them get the opportunity to do so, the rest miss the opportunity because of limited chances. The theory therefore assumes that few numbers of individuals emerge as leaders not because they want to benefit themselves, but it is because they have the desire to serve others and they do so on behalf of those who missed the opportunity. The key tenets of this theory are based on devotedness and desire to serve others. Spears (1996) expanded the work of Greenleaf by exploring four central tenets which, if taken separately, they basically present a fuller picture of SLP framework pin-pointing the fundamental principles of the theory itself. The four tenets can be identified and expounded as;

\subsubsection{Increased Service to Others}

The central idea of this tenet stands on a strand that servant-leadership begins when a leader assumes the role of a servant to others interacting with followers. It is held that a servant-leader's primary motive is to serve others with quality services encouraging greatness in them. The legitimacy of a servant leader arises not from the exercise of his power or self-interested actions, but it is from his fundamental desire to first help others. According to Greenleaf (1970) the desire to serve others first is the fundamental simple fact and the central key to a leader's greatness. 


\subsubsection{Holistic Approach to Work}

The servant leadership philosophy holds that the work exists for the person as much as the person exists for the work (Greenleaf, 1996). The philosophy poses challenges on institutions to rethink about the relationships that exist amongst people themselves, their institutions and society as a whole. It promotes a view that individuals should be encouraged to be who they are in their professional as well as personal lives and consequently to have holistic approach in doing their common interest works. Greenleaf (1996) contends that this integrated valuation of individuals ultimately benefits the long-term interests and performance of the society as a whole.

\subsubsection{Promoting a Sense of Community}

Servant leadership philosophy questions on institution's ability, in this case the government, to provide the community with good social services. The philosophy argues that only a community, which is defined as groups of individuals that are jointly liable for each other both individually and as a unit, can perform this function (Greenleaf, 1998; Lawrance and Spears, 2004). It also emphasizes that it is only by establishing this sense of community among followers can an organization or a community succeed in its objectives. However, Greenleaf (1996) further contends that the sense of community can arise only from the actions of individuals who are servant leaders.

\subsubsection{Sharing of Power in Decision-Making}

This tenet emphasizes that followers are not mere sheep; for they have ability to think and weigh things before making their decisions. Thus, an effective servant leader is supposed to involve them in deciding the aftermath of their common interests. By so doing, a servant leader is said to cultivate in his followers the spirit of servant-leadership by nurturing participatory and empowering them and encouraging their talents. In that case, the servant-leader creates a more effective, motivated workforce and ultimately a more successful organization or society. As pointed out by Russell (2001), servant leaders enable others to act not by hoarding the power they have but by giving it away.

Generally, there has been a flurry of interest in recent years surrounding this philosophy of servant leadership and the dimensions that make up its construct. The servant leadership has become a theory for moral and ethical leadership that focuses on follower's development, community building, authentic and shared leadership (Graham, 1991; Sendjaya and Sarros, 2002; Patterson, 2003; Dennis, 2004; Laub, 2004). That is why Spears (1996) sees it as a new kind of leadership model which opens a new ground of emphasis on the basic human rights and social development that any human being would like to have through its fundamental principles of increased service to others; a holistic approach to work; promoting a sense of community; and the sharing of power in decision-making.

\subsection{The Conceptual Model}

A conceptual model is an assemblage set of research concepts cum variables together with their logical relationship often represented in the form of diagrams, charts, graphs, 
organograms, pictographs, flow-charts or mathematical equations (Mason, 2002; Rickman, 2005). In its expected nature, a well-constructed conceptual model is argued to be a fundamental attempt of providing logical and tentative solutions to research raised questions. The conceptual model of this study is based on assessing the prospects and challenges of adopting the servant leadership philosophy in addressing public leadership deficiencies especially in the political leadership context and it is summarized in a simple model as shown in Figure 1.

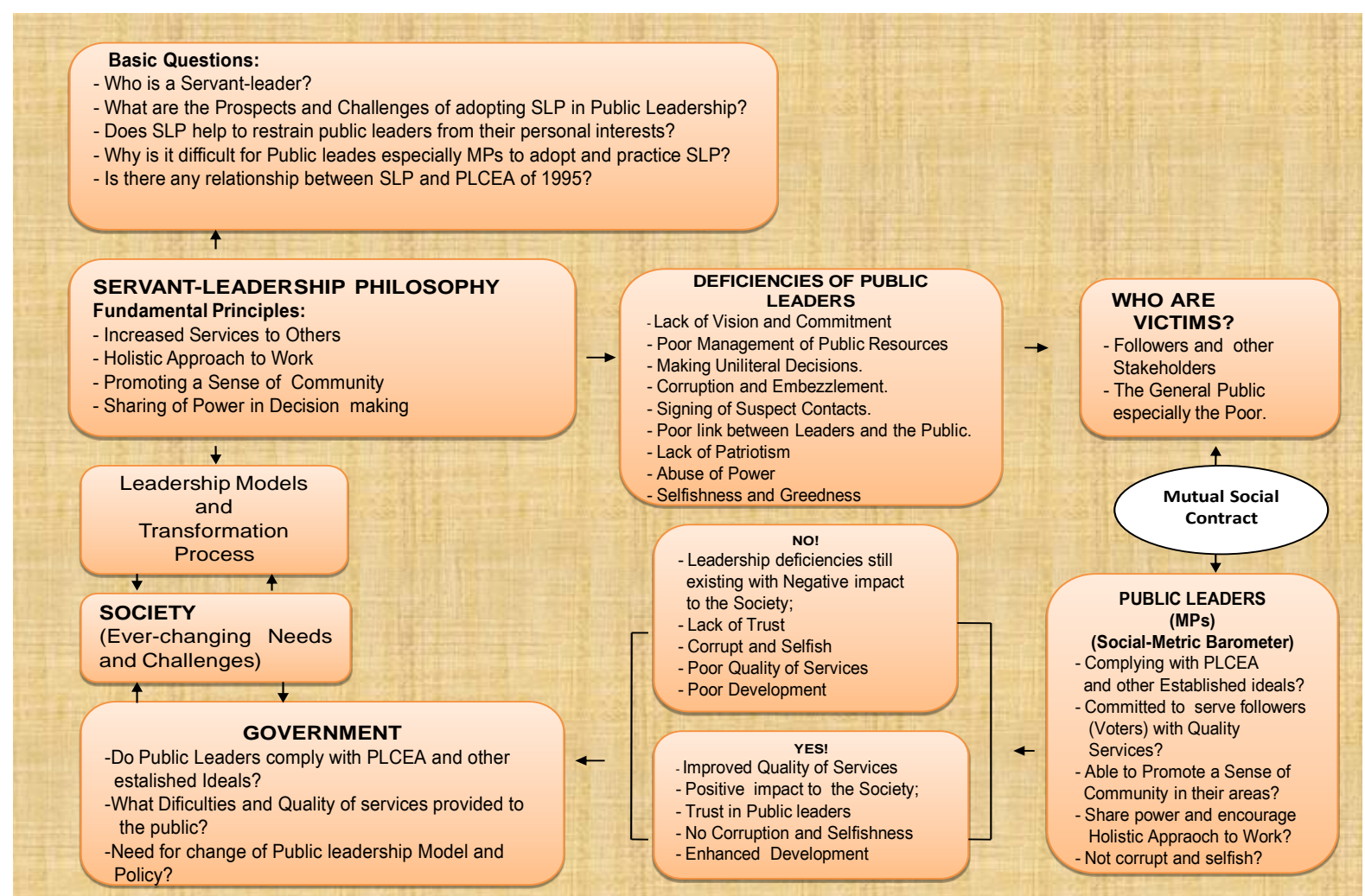

Figure 1. The impact of servant leadership philosophy in addressing public leadership deficiencies

\subsection{Empirical Literature Review}

Spears (1996) argues that SLP crosses all boundaries and is being applied by a wide variety of people working for myriad organizations. Lawrance and Spears (2004) emphasize that individuals within such organizations have adopted servant leadership as a guiding corporate philosophy and as a foundation for their mission. There are vivid examples of successful organizations mainly concentrated in North America which have adopted this philosophy of servant-leadership. For instance, TD Industries, a Dallas-based mechanical contractor, has been over 30 years, advocating and executing the servant-leadership philosophy as their central corporate culture. Ben Houston, the TD Industries Managing Director, (in Spears, 1996) contends that the mission is so serious that if you get the business results without the servant leadership, you cannot stay there. Perhaps that is the reason behind TD Industries being consistently rated among the best companies to work for in America by Fortune 
Magazine for over the last 30 years (Lawrance and Spears, 2004). It is reported by the Fortune Magazine (2017) that, out of the listed 100 best companies to work for in America, 17 companies are servant-leadership led companies while 5 of them are in the list of the best top 10 leading companies including; SAS Company (ranked the first), Wegmans Food Market (3rd), Zappos.com (6th), Nugget Market (8th) and Recreational Equipment (9th).

The studies made by Mbiti (1969), Gakuru (1998), Kosha (2005), Bell (2002) and Nelson (2003) on African organizations indicate that increased services to the community and decisions based on a consensus are traditionally major concerns of African societies. They also reveal that welfare of every individual in the African community means the welfare of the entire community. Therefore, servant leadership philosophy was practiced in different forms like Harambee, Ubuntu and Ujamaa (Nyerere, 1968: Bell, 2002). This idea is explicitly articulated by a Nigerian novelist, Chinua Achebe, who writes: "whereas an animal scratches itself against a tree, a human being has a kinsman to scratch it for him" (Gakuru, 1998:11). Both Mbiti (1969) and Bell (2002) commonly agree on promoting a sense of community amongst Africans - which is one of the four pillars of servant leadership - when they both warn that Africans should not think of themselves as discrete individuals but rather understand themselves as part of a community.

A study made by Kosha (2005) based on Kenyan industries showed that both workers and managers preferred a modern democratic style of leadership to build consensus and trust. Extending the research of Patterson (2003) on SLP, Kosha (2005) explores the acceptability and applicability of servant leadership philosophy's construct of service in the Kenyan context. The study examined 25 leaders and managers from varied organizational settings. From the analysis of the responses, it emerged that (a) role modeling, (b) sacrificing for others, (c) meeting the needs of others (employees) and developing them, (d) service as a primary function of leadership, (e) recognizing and rewarding employees, (f) treating employees with respect (humility), and (g) involving others in decision making are prevalent themes reminiscent to Patterson's servant leadership theory's construct of service. The research findings thus concludes that the construct of service has acceptability and applicability among Kenyan leaders and managers. However, the research findings still lack reliability and they are subjected to challenges on the grounds that the sample involved was too small to reveal the reliable conclusion taking Kenya as a whole.

It is generally held that increased service and commitment, a sense of community and consensual decisions amongst leaders are critical variables to be maintained in African societies if both emerging democracy and development are to be attained (Gakuru, 1998; Kosha, 2005). Ayittey (1992) stresses by giving examples how traditional African leaders placed the community's interest ahead of theirs revealing that the chief did not rule, but rather served and only led by consensus. In situations where the council (governing body) failed to reach a consensus, the chief would call a village assembly (representatives) to put the issues before the people for debate. This example shows how public leaders are supposed to put their communities' interests ahead of theirs and share power with their followers. 


\section{Methodology}

A case study design was employed and it involved both qualitative and quantitative approaches. The qualitative and quantitative approaches were integrated in this study basing on the views of Enon (1998) and Kothari (2004) who suggest that it is essential to integrate the two approaches in order to enhance validity and reliability of the research findings. Thus, during the study a sequential strategy was used as recommended by Creswell (2009) where a qualitative approach was used first through text analysis, questionnaires and observation to explore data on the phenomenon, then, quantitative approach followed for analyzing the generated data. The population involved in this study consisted of MPs from the Parliament of the United Republic of Tanzania, key informants from a number of institutions whose roles and functions are much related to the study and respondents from the general public.

The study had an estimated sample of 300 respondents supposed to be drawn from three categories; 120 MPs from the Parliament of the United Republic of Tanzania, 90 key informants from selected institutions whose functions and roles bear an essential contribution to the study including; Bunge officials, Ex-MPs, Registrar of political parties and leaders from political parties, respondents from academic institutions, the Judiciary of Tanzania and Commission for Human Rights and Good Governance (CHRAGG). Others include religious leaders, Tanzania Gender Networking Programme (TGNP), TWAWEZA and Research for Poverty Alleviation (REPOA). The third category comprised of 90 respondents from the general public. The expected number of key respondents (120 MPs) comprised $33.61 \%$ of the total number of 357 MPs of the Parliament of the United Republic of Tanzania. Primary data were obtained from the selected respondents through semi-structured interviews and questionnaires. The obtained primary data were found to be more useful and consistent to the research problem on the ground that they were collected for a specific problem at hand. Also, secondary data were collected from various sources such as Bunge hansards, reports and publications; different speeches and the Bunge website; other sources were libraries, text books, journals and newspapers.

\section{Results}

Out of the estimated sample size of 300(100\%) respondents, 278(92.67\%) of them responded during the study; the rest $22(7.33 \%)$ had various reasons to justify their absence. This response rate is found to be appropriate as argued by Sekaran (2003) that any response rate above $75 \%$ in the study is classified as best response rate and is believed to provide reliable information. But also, this response rate is found to be higher and liable compared to those of the previous studies made by other scholars such as Awino (2007) who had a response rate of $57 \%$ and Abok et. al (2013) who had a response rate of 55\% respectively from the target population of their studies. The response rate of this study is further supported by Mugenda and Mugenda (2003) who contend that, in conducting a study, any response rate at the extent of $50 \%$ is said to be sufficient, $60 \%$ is good and $70 \%$ and above is said to be excellent. Therefore, it is clearly believed that the response rate of this study is excellent and hence provides reliable information. 
The first research question of this study was designed to assess the prospects and challenges of adopting the fundamental principles of servant leadership philosophy proposed for public leaders as a way of addressing deficiencies in the Tanzania public leadership. The data was mainly collected through distributed questionnaires and informal discussions made to $109(90.83 \%)$ out of 120(100\%) MPs estimated in the sample and 90(100\%) RGPs. Data was also collected through semi-structured interviews conducted to $79(87.78 \%)$ out of $90(100 \%)$ key informants estimated in the sample. The respondents had to give their views on how they think and feel about MPs in connection to servant leadership philosophy and why they hold such opinions. Then, the collected data was analyzed being divided into two categories; the first category was that of views on the prospects of adopting, and the second one was that of the challenges which might be experienced in the due process of adopting the principles of servant leadership philosophy.

\subsection{Views on the Prospects of Adopting Principles of Servant Leadership}

In order to allow objective analysis of their views, respondents were purposely divided into three categories of MPs, key informants and RGPs. Then, the employed data collection tools were used to collect views of each category on how they thought about the prospects of adopting the principles of servant leadership in public leadership particularly by MPs.

\subsubsection{MPs' Views on the Prospects}

The 109 MPs who participated in the study formed the first category. They were supplied with questionnaires requesting them to give their views on whether there are prospects for them to adopt the principles of SLP in the due process of discharging their duties and responsibilities. The research findings revealed that $73(66.97 \%)$ out of $109(100 \%) \mathrm{MPs}$ involved in the study were of the views that there are 'very high' prospects while $20(18.35 \%)$ said 'high' and 12(11.01\%) said there are 'moderate' prospects. There were only 4(3.67\%) MPs who said there are 'low' prospects for adopting the principles of servant leadership. Table 4.1 shows in detail the responses of all MPs involved in the study.

Table 4.1. Views of MPs on the prospects of adopting servant leadership philosophy

\begin{tabular}{|c|c|c|c|}
\hline & No. of MPs & involved $(\mathrm{N}=109)$ & \\
\hline Answer options: & Male & Female & Total \\
\hline A: Very High & $68(62.39 \%)$ & $5(4.59 \%)$ & $73(66.97 \%)$ \\
\hline B: High & $17(15.60 \%)$ & $3(2.75 \%)$ & $20(18.35 \%)$ \\
\hline C: Moderate & $11(10.09 \%)$ & $1(0.92 \%)$ & $12(11.01 \%)$ \\
\hline D: Low & $3(2.75)$ & $1(0.92 \%)$ & $4(3.67 \%)$ \\
\hline TOTAL & $99(90.83 \%)$ & $10(9.17 \%)$ & $109(100 \%)$ \\
\hline
\end{tabular}

Source: Research Data, 2015

In order to enhance clarity, the views of MPs on whether there are prospects for adopting the principles of SLP were also analyzed using a graph as shown in Figure 2. The graph shows clearly that more than two-thirds $73(66.97 \%$ ) of the MPs participated in the study had the views that there are 'very high' prospects in adopting the principles of servant leadership. The 
research findings have also impliedly shown that there is a major difference between traditional leadership and servant leadership in terms of their focus and intention.

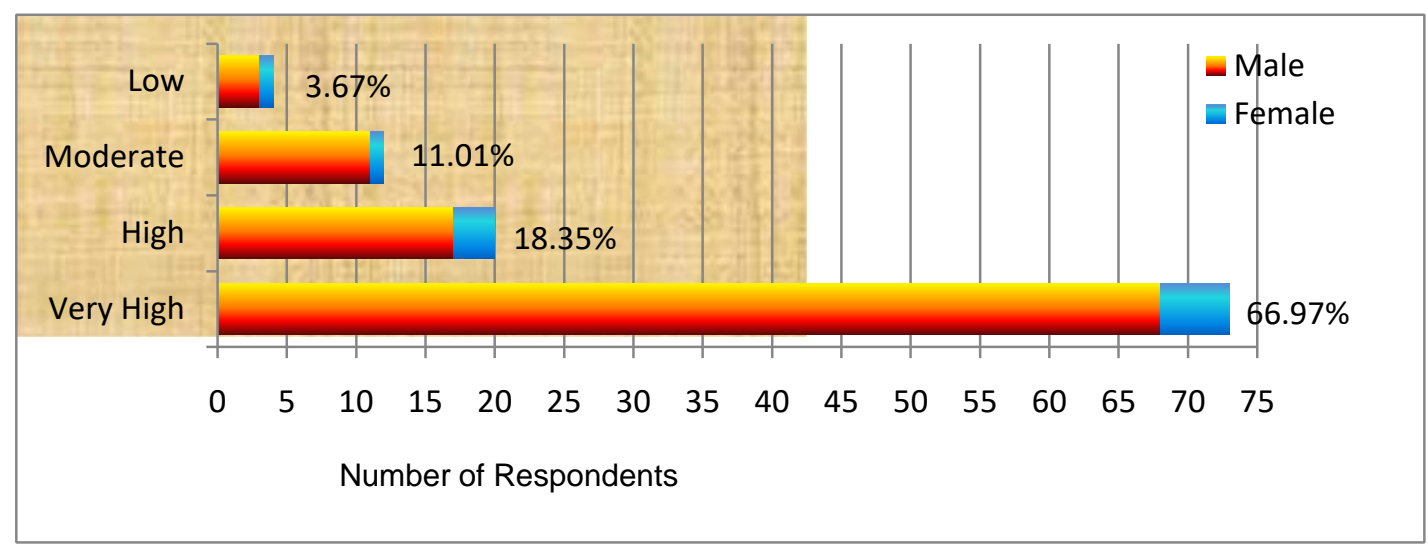

Figure 2. Detailed analysis of MPs' views on the prospects of adopting SLP

Source: Research Data, 2015

The traditional leadership, as insisted by Dambe and Moorad (2008), generally involves the accumulation and exercise of power - a leader being at the top of the pyramid and the led at the bottom. Unlike a servant leader whose intention focuses primarily on the growth and well-being of his people, a traditional leader tends to pay much attention on maintaining power and thus paying less respect to the human aspect. In that view, it is obvious that people would prefer a servant leader to a traditional one. For a servant leader as observed by Greenleaf (1977) tends to elevate individuals in the society to the same status of the leader himself which is not the case to the traditional leader. That is why McGee-Cooper and Trammell (2013) declare that servant leaders are the only true heroes of the $21^{\text {st }}$ Century who are quietly working out of the spotlight to transform the world.

\subsubsection{RGPs' Views on the Prospects}

This was the second category composed of 90 respondents from the general public. All respondents in this category were supplied with questionnaires written in Swahili requesting them to give their views on whether there are prospects for MPs adopting SLP in the due process of discharging their duties and responsibilities. But before supplying them with questionnaires a brief informal discussion was held to each RGP to enlighten them on the study but also to confirm their ages if were above 18. During the process of collecting the questionnaires, some comments and opinions were welcomed and noted down as part of the views from the respondents. The specific identified reason for changing questionnaires into Swahili for this category was the results of the pre-test that was made before to 3 RGPs which showed that $1(33.33 \%)$ out of the $3(100 \%)$ respondents tested was not fluent in English.

The research findings from this category revealed that $48(53.33 \%)$ out of $90(100 \%)$ respondents from the general public who participated in this study agreed that there are very high prospects while $23(25.55 \%)$ said 'high' and $14(15.56 \%)$ said there are 'moderate 
prospects. Only $5(5.56 \%)$ out of $90(100 \%)$ respondents from this category had the views that there are 'low prospects. Table 4.2 shows in detail responses of all respondents from this category involved in the study. The research findings justified what Kahl (2004) pointed out when explaining about quality leadership that some public leaders especially from the political wing are self-centered with no intention of serving their people rather than enriching themselves. In this case, the research findings for example revealed that 21(23.33\%) of the RGPs involved in the study had the views that although SLP was found to be of high prospects, the self interest of their MPs as political leaders was a major challenge that prevent them and other public leaders from adopting it in their due process of discharging their duties and responsibilities.

Table 4.2. RGPs' views on the prospects of adopting servant leadership philosophy

\begin{tabular}{|c|c|c|c|}
\hline \multirow[b]{2}{*}{ Answer options: } & \multicolumn{3}{|c|}{ No. of MPs involved $\quad(\mathrm{N}=90)$} \\
\hline & Male & Female & Total \\
\hline A: Very High & $30(33.33 \%)$ & $18(20.00 \%)$ & $48(53.33 \%)$ \\
\hline B: High & $12(13.33 \%)$ & $11(12.22 \%)$ & $23(25.55 \%)$ \\
\hline C: Moderate & $9(10.00 \%)$ & $5(5.56 \%)$ & $14(15.56 \%)$ \\
\hline D: Low & $3(3.34)$ & $2(2.22 \%)$ & $5(5.56 \%)$ \\
\hline Total & $54(90.83 \%)$ & $36(40.00 \%)$ & $90(100 \%)$ \\
\hline
\end{tabular}

Source: Research Data, 2015

As shown in Figure 3, the views of respondents from the general public involved in this study on whether there are prospects for MPs adopting the principles of servant leadership in the due process of discharging their duties and responsibilities were also analyzed using a graph to enhance clarity.

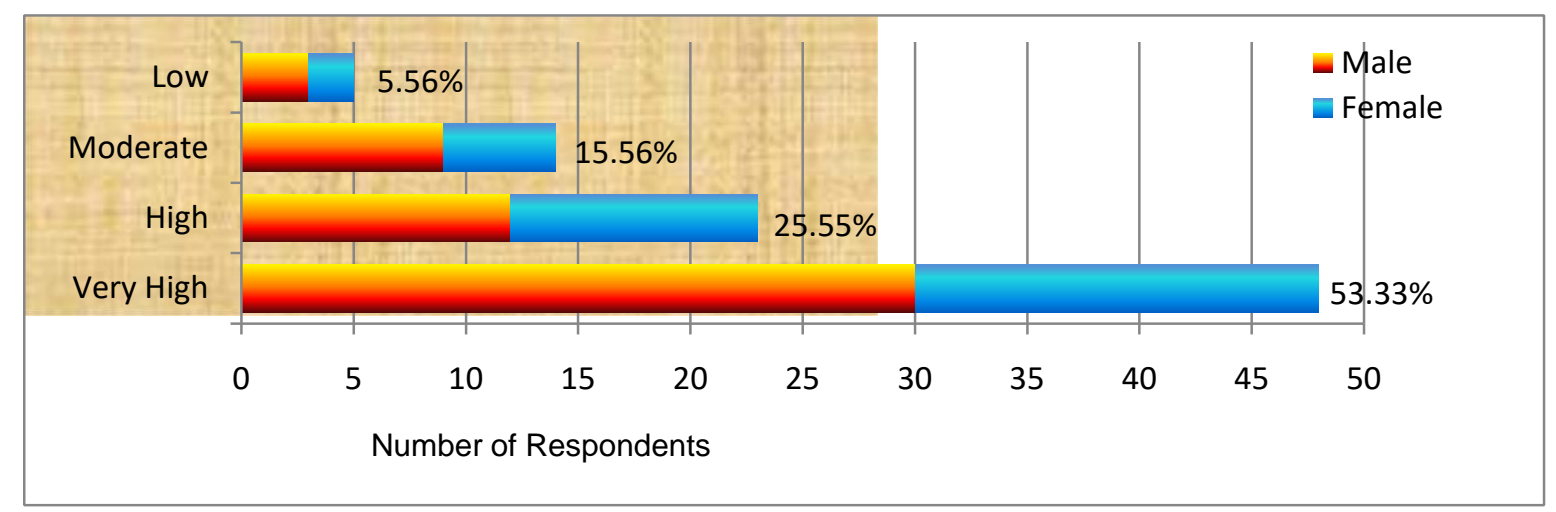

Figure 3. Detailed analysis of RGPs' views on the prospects of MPs adopting SLP

Source: Research Data, 2015

The graph clearly shows that $71(78.89 \%)$ out of $90(100 \%)$ respondents from the general public participated in the study agreed to the extent of 'very high' $48(53.33 \%)$ and 'high' $23(25.55 \%)$ that there are prospects for MPs to adopting the principles of SLP if they want to serve their voters with increased services. Only a number of $19(21.11 \%)$ less than a quarter of 


\section{Macrothink}

$90(100 \%)$ respondents from this category had their views ranging from 'moderate' $14(15.56 \%)$ and 'low' 5(5.56\%).

\subsubsection{Key informants' Views on the Prospects}

The 79 key informants participated in the study formed the third category. The views of respondents from this category were obtained through semi-structured interviews. Basically, this was the strategic category containing key personalities who were expected to give important information because of their knowledge related to the study and nature of activities of their institutions. In that view, the process of obtaining information from this category (interviewing them) was purposely done after analyzing the data obtained from the first two categories of MPs and RGPs in order to cross-check and obtain more clarifications and extra information on some important issues. The findings of the conducted interviews on whether there are prospects for MPs to adopting principles of SLP revealed that 46(58.23\%) out of $79(100 \%)$ involved in the study were of the views that there are 'very high' prospects while $25(31.65 \%)$ said 'high' and 5(6.32\%) said there are 'moderate' prospects. Only 3(3.80\%) out of the $79(100 \%)$ involved key informants responded that there are 'low' prospects. Table 4.3 shows in detail the interview responses of key informants involved in this study.

Table 4.3. Interview results of key informants on the prospects of adopting SLP

\begin{tabular}{|c|c|c|c|}
\hline \multirow[b]{2}{*}{ Answer options: } & \multicolumn{2}{|c|}{ No. of key informants involved } & $(\mathrm{N}=79)$ \\
\hline & Male & Female & Total \\
\hline A: Very High & $36(45.57 \%)$ & $10(12.66 \%)$ & $46(58.23 \%)$ \\
\hline B: High & $20(25.32 \%)$ & $5(6.33 \%)$ & $25(31.65 \%)$ \\
\hline C: Moderate & $3(3.80 \%)$ & $2(2.52 \%)$ & $5(6.32 \%)$ \\
\hline D: Low & $2(2.53)$ & $1(1.27 \%)$ & $3(3.80 \%)$ \\
\hline Total & $61(77.22 \%)$ & $18(22.78 \%)$ & $79(100 \%)$ \\
\hline
\end{tabular}

Source: Research Data, 2015

For the purpose of enhancing clarity, the collected views of key informants were analyzed using a graph as shown in Figure 4. The graph clearly shows that majority of the respondents $71(89.87 \%)$ out of $79(100 \%)$ key informants participated in the study agreed to the extent of 'very high' $48(58.23 \%)$ and 'high' $25(31.65 \%)$ that there are prospects for MPs to adopting the principles of servant leadership in the due process of discharging their duties and responsibilities. 


\section{Macrothink}

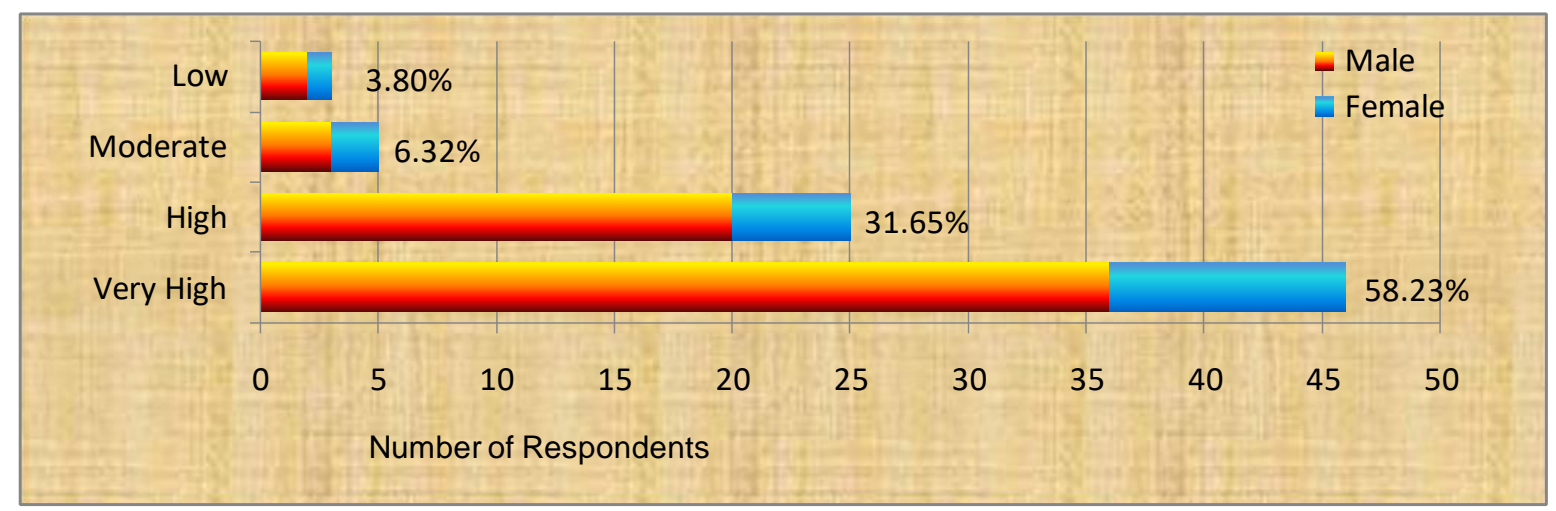

Figure 4. Detailed analysis of key informants' views on the prospects for MPs adopting SLP

Therefore, the findings of this study support that self interest of public leaders stems from the natural behaviour of a human being as contended by Hobbes (1651) and Dewey (1922). But also emphasize that always public leaders' behaviour should be controlled in order to restrain them from misusing their powers for personal gains. In that respect, if Tanzania needs to adopt the servant leadership philosophy as one of the means of addressing deficiencies in its public leadership, then, self interests of public leaders is one of the challenges that should be properly checked and mitigated.

On the other hand, the conducted interview aimed at collecting views from key respondents on specific prospects that might be obtained if at all this philosophy of servant leadership would have been adopted in the Tanzania public leadership framework. In that respect, an open-ended question to allow more information was included in the semi-structured interview guideline protocol requesting for information from key informants about prospects which they thought in their opinions could be obtained from adopting the servant leadership philosophy in the public leadership framework. During the interview much information was given and most of it was found to be repetitive. The information also found to reflect what were being mentioned by some respondents from the first and second categories who had a moment to informally discuss with the researcher. In that case, synthesis was made during the data analysis process to consolidate them into a short list of properly arranged prospects as shown in Table 4.4 .

Table 4.4. A summarized list of prospects of adopting SLP in the public leadership

- Puts more weight on services delivery to the public rather than looking at personal interests;

- Acts as a tool for moulding public leaders from tyrannic masters into devoted public servants;

- Promotes a sense of community and inculcates patriotism amongst public leaders and a society as whole.

- It is a ladar to a harmonious society cultivating a spirit of holistic approach to work;

- Allows sharing of power through public involvement in decision making process;

- Insists on building a corrupt free society with equitable sharing of public resources;

- Helps to bring public leaders closer to the people they lead and thus to establish trust and strong-bond between them;

- Promotes human dignity and social equality through its principles which are people-centred. 
Source: Research Data, 2015

Generally, the research findings proved that there are prospects for MPs adopting the principles of SLP. A list of prospects have been produced as a result of semi-structured interviews and informal discussions held with respondents as a proof whereas 167(60.07\%) respondents out of the $278(100 \%)$ participated in the study indicated that the prospects are 'very high' while $68(24.46 \%)$ said there are 'high'. However, there was a small group of respondents who indicated that there are 'low" prospects of adopting these principles. Table 4.5 shows the general summary of the responses from all respondents participated in the study.

Table 4.5. Summary of views of all respondents on the prospects of adopting SLP

\begin{tabular}{|c|c|c|c|c|}
\hline \multirow[t]{2}{*}{ Answer options: } & \multicolumn{4}{|c|}{ No. of Total Respondents } \\
\hline & MPs & Key Informants & RGPs & Total \\
\hline A: Very High & $73(26.26 \%)$ & $46(16.55 \%)$ & $48(17.27 \%)$ & $167(60.07 \%)$ \\
\hline B: High & $20(7.19 \%)$ & $25(8.99 \%)$ & $23(8.27 \%)$ & $68(24.46 \%)$ \\
\hline C: Moderate & $12(4.32 \%)$ & $5(1.80 \%)$ & $14(5.04 \%)$ & $31(11.15 \%)$ \\
\hline D: Low & $4(1.44)$ & $3(1.08 \%)$ & $5(1.80 \%)$ & $12(4.32 \%)$ \\
\hline Total & $109(39.21 \%)$ & $79(28.42 \%)$ & $90(32.37 \%)$ & $278(100 \%)$ \\
\hline
\end{tabular}

Source: Research Data, 2015

To enhance clarity, the summary of views of all respondents involved in this study was also analyzed using a graph. As it is revealed in Figure 5, they were only 12(4.32\%) respondents As it is revealed in Figure 5, they were only 12(4.32\%) respondents out 278(100\%) involved in the study who had the views that there was 'low' prospects for MPs adopting the principles of servant leadership philosophy in the due process of discharging their duties and responsibilities.

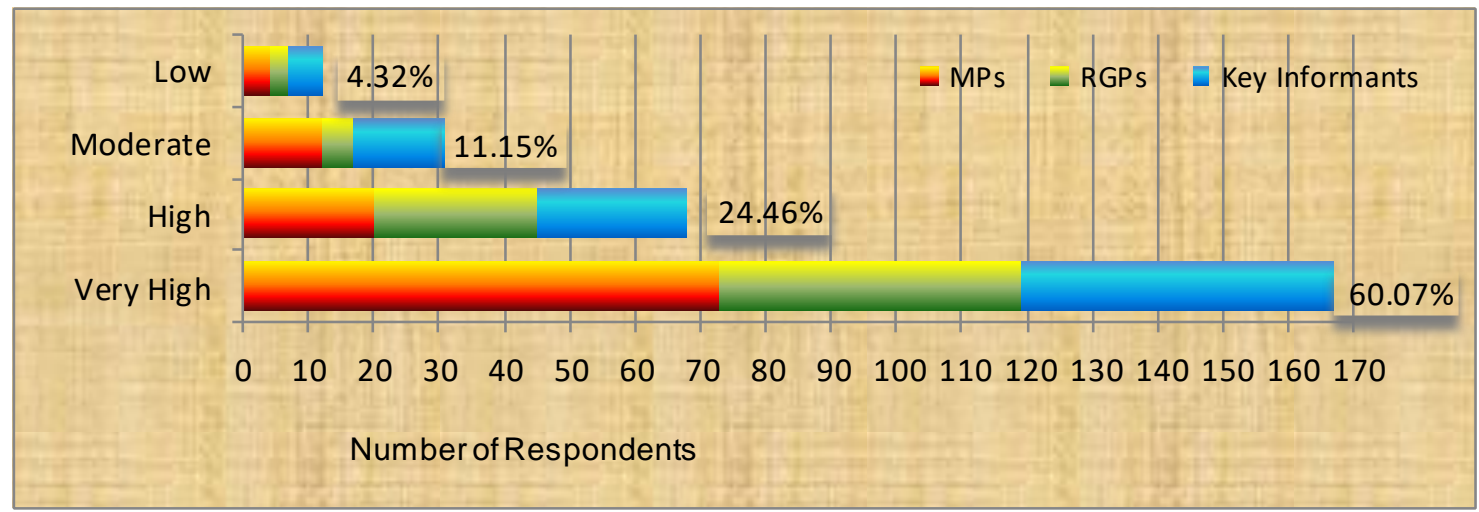

Figure 5. Detailed analysis of views of all respondents on the prospects of adopting SLP

\subsection{Views on the Challenges of Adopting Servant Leadership Philosophy}

The second part of the first research question was sought to inquire information about the challenges that prevent MPs from adopting the principles of SLP in the due process of discharging their duties and responsibilities. The views of all involved respondents were 
collected in respect of their categories using the employed data collection tools.

\subsubsection{MPs' Views on the Challenges}

MPs were requested to give their views on the types of challenges which impede them as public leaders from the political wing to adopt the principles of SLP in the due process of discharging their duties and responsibilities. The research findings revealed that 25(22.94\%) out of $109(100 \%)$ MPs participated in this study were of the views that ignorance of the philosophy of leaders was the major challenge in adopting the principles of SLP while $22(20.18 \%)$ mentioned self-interests of leaders and 21(19.27\%) mentioned the lack of political will to be the major challenges. The research findings also revealed that there were two sub-clusters of $19(17.43 \%)$ and 18(16.51\%) MPs who mentioned a weak legal framework to control conflict of interests of leaders and lack of patriotism of leaders respectively to be the major challenges to the adoption of the principles of the philosophy of servant leadership. On the other hand, the study revealed that there was a sub-cluster of 4(3.67\%) MPs in this category who pointed out that there are more reasons than the mentioned ones which contribute to the challenges of adopting the principles of servant leadership in the Tanzania public service. Table 4.6 shows in detail the responses of all respondents from this cluster.

Table 4.6. Views of MPs on challenges of adopting SLP

\begin{tabular}{|c|c|c|c|}
\hline \multirow[b]{2}{*}{ Answer options: } & \multicolumn{3}{|c|}{ No. of MPs involved $\quad(N=109)$} \\
\hline & Male & Female & Total \\
\hline A: Ignorance of the Philosophy & $22(20.18 \%)$ & $3(2.75 \%)$ & $25(22.94 \%)$ \\
\hline B: Self-interests of Leaders & $20(18.35 \%)$ & $2(1.83 \%)$ & $22(20.18 \%)$ \\
\hline C: Lack of Political Will & $20(18.35 \%)$ & $1(0.92 \%)$ & $21(19.27 \%)$ \\
\hline D. Weak legal framework to control conflict of interes & $18(16.51 \%)$ & $1(0.92 \%)$ & $19(17.43 \%)$ \\
\hline E. Lack of Commitment and Patriotism of Leaders & $16(14.68 \%$ & $2(1.83 \%)$ & $18(16.51 \%)$ \\
\hline F. Other reasons & $3(2.75 \%)$ & $1(0.92 \%)$ & $4(3.67 \%)$ \\
\hline Total & $99(90.83 \%)$ & $10(9.17 \%)$ & $109(100 \%)$ \\
\hline
\end{tabular}

Source: Research Data, 2015

To provide more clarity, the views of MPs on the challenges that prevent them from adopting the principles of SLP in the due process of discharging their duties and responsibilities were also analyzed using a graph as shown in Figure 6. The graph reveals that, except for the views given for the option of 'other reasons' which is 4(3.67\%), there was an even distribution of views given by MPs on the first five listed challenges ranging in total from $18(16.51 \%)$ to $25(22.94 \%)$. However, the views given on the reason that 'ignorance of the philosophy' suggest that this was the major challenge for MPs to adopt SLP in their due process of discharging their duties and responsibilities. 


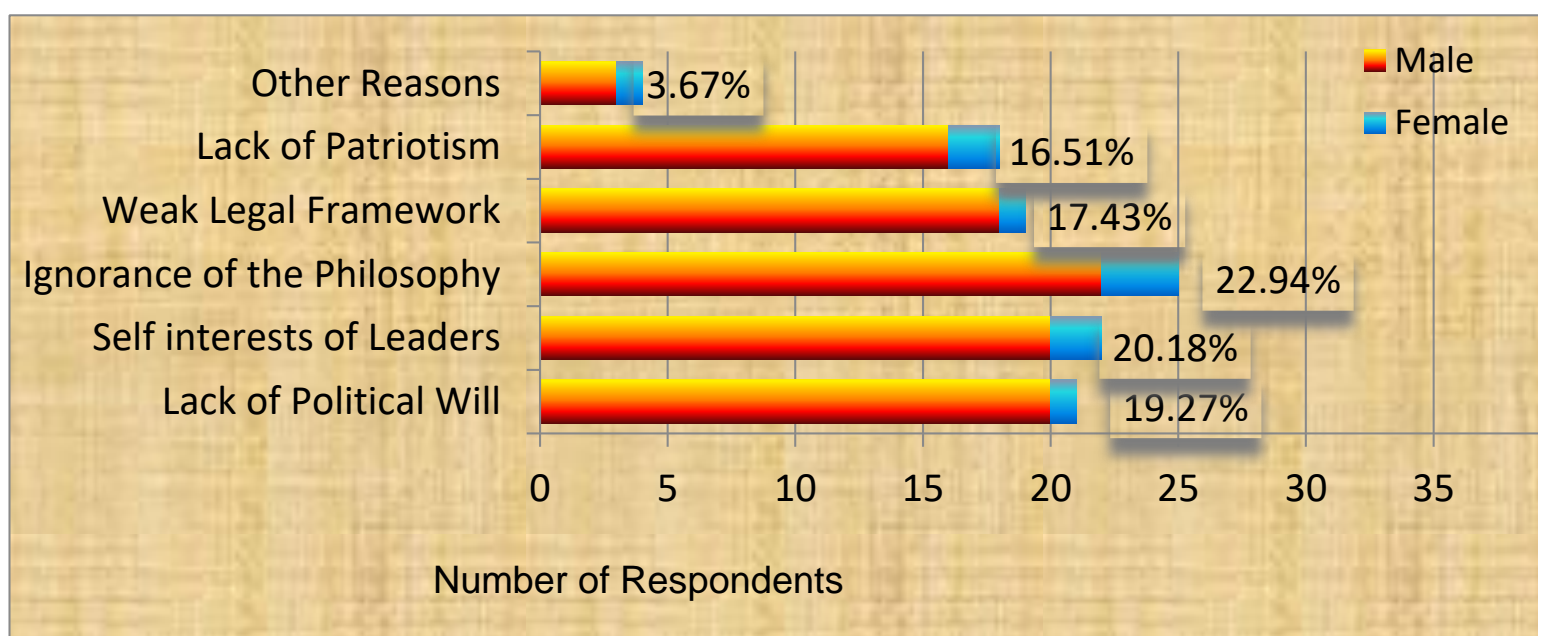

Figure 6: Analysis of MPs' views on the challenges that prevent them from adopting

SLP

Source: Research Data, 2015

\subsubsection{RGPs' Views on the Challenges}

In collecting views from RGPs on the types of challenges which prevent MPs from adopting the principles of SLP in discharging their duties and responsibilities, the employed data collection tools were used. The RGPs were supplied with questionnaires after a brief informal discussion and age confirmation. The questionnaires for this category as it has been explained, was written in Swahili to allow language fluency. The research findings revealed that $23(25.56 \%)$ out of $90(100 \%)$ RGPs involved in the study were of the views that lack of political will was the major challenge while 21(23.33\%) RGPs indicated self-interests of leaders to be the challenge; and others $15(16.67 \%)$ pointed out that ignorance of the philosophy seemed to be a challenge to the adoption of the philosophy. Likewise, there were two RGPs' sub-clusters of $14(15.56 \%)$ and $12(13.33 \%)$ whose views revealed that a weak legal framework to control conflict of interest and lack of patriotism of leaders respectively were major challenges for MPs towards the adoption of the principles of SLP in discharging their duties and responsibilities. However, the research findings revealed that there was a sub-cluster of 5(5.56\%) RGPs in this cluster who believed that there are other more reasons than the mentioned ones which contribute to the challenges of adopting the principles of servant leadership to MPs. Table 4.7 shows in detail responses of all respondents from this cluster involved in the study. 
Table 4.7. Views of RGPs on the challenges of adopting SLP

\begin{tabular}{lccc}
\hline & \multirow{2}{*}{ No. of } & Respondents involved & (N=90) \\
\cline { 2 - 4 } Answer options: & Male & Female & Total \\
\hline A: Ignorance of the Philosophy & $8(8.89 \%)$ & $7(7.78 \%)$ & $15(16.67 \%)$ \\
B: Self-interests of Leaders & $12(13.33 \%)$ & $9(10.00 \%)$ & $21(23.33 \%)$ \\
C: Lack of Political Will & $13(14.44 \%)$ & $10(11.11 \%)$ & $23(25.56 \%)$ \\
D. Weak legal framework to control conflict of interest & $8(8.89 \%)$ & $6(6.67 \%)$ & $14(15.56 \%)$ \\
E. Lack of Commitment and Patriotism of Leaders & $9(10.00 \%)$ & $3(3.33 \%)$ & $12(13.33 \%)$ \\
F. Other reasons & $4(4.44 \%)$ & $1(1.11 \%)$ & $5(5.56 \%)$ \\
\hline TOTAL & $54(60.00 \%)$ & $36(40.00 \%)$ & $90(100 \%)$ \\
\hline
\end{tabular}

Source: Research Data, 2015

The views of RGPs on challenges that prevent MPs from adopting the principles of SLP were also analyzed using a graph as shown in Figure 7. The graph generally reveals that the lack of political will with $23(25.56 \%)$ respondents was the most leading challenge followed by self-interests of leaders with $21(23.33 \%)$ respondents and ignorance of the philosophy with $15(16.67 \%)$. With exception of 'other reasons' which had 5(5.56\%) respondents, the distribution of responses in the other five stated challenges were almost even indicating that the gravity of the mentioned challenges were considerably relevant and applicable.

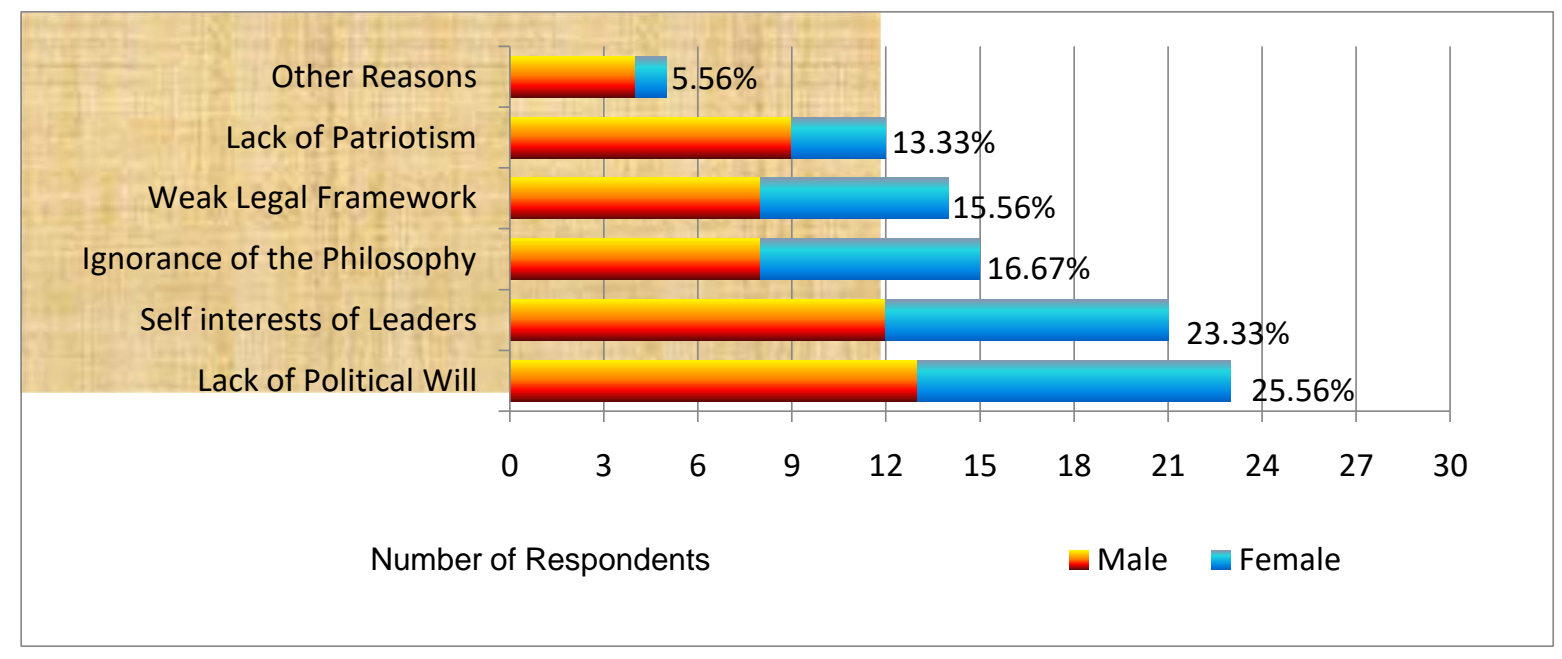

Figure 7. Detailed analysis of the views of RGPs on the challenges of adopting SLP

Source: Research Data, 2015

\subsubsection{Key Informants' Views on the Challenges}

The data and views of respondents from this category were obtained through employed data collection instruments of semi-structured interviews. The key informants were requested to give their views on the types of challenges which prevent MPs from adopting the principles of SLP. The research findings revealed that 20(25.32\%) out of 79(100\%) key informants were of the views that lack of political will was the major challenge while $15(18.99 \%)$ pointed out 
self-interests of leaders to be the major challenge and others $15(18.99 \%)$ had the views that weak legal framework to control the conflict of interest of leaders was a challenge to the adoption of the philosophy. Also, there was a sub-cluster of 14(17.72\%) key informants who had views that ignorance of the philosophy was a major challenge to the adoption of SLP. There was only a sub-cluster of 3(3.80\%) in this category who had views that there are other more reasons than the mentioned ones which contribute to the challenges of adopting the principles of SLP. When requested to mention those other reasons, they pointed out that the dream of adopting SLP in our public leadership may only come true if poverty and corruption problems are properly addressed. Table 4.8 shows in detail responses of all respondents from this category involved in the study.

Table 4.8. Key Informants' Views on Challenges of Adopting SLP

\begin{tabular}{lccc}
\hline & No. of key informants & involved $(\mathrm{N}=79)$ \\
\cline { 2 - 4 } Answer options: & Male & Female & Total \\
\hline A: Ignorance of the Philosophy & $11(13.92 \%)$ & $3(3.80 \%)$ & $14(17.72 \%)$ \\
B: Self-interests of Leaders & $10(12.66 \%)$ & $5(6.33 \%)$ & $15(18.99 \%)$ \\
C: Lack of Political Will & $16(20.25 \%)$ & $4(5.06 \%)$ & $20(25.32 \%)$ \\
D. Weak legal framework to control conflict of interest & $12(15.19 \%)$ & $3(3.80 \%)$ & $15(18.99 \%)$ \\
E. Lack of Commitment and Patriotism of Leaders & $10(12.66 \%)$ & $2(2.53 \%)$ & $12(17.72 \%)$ \\
F. Other reasons & $2(2.53 \%)$ & $1(1.27 \%)$ & $3(3.80 \%)$ \\
\hline Total & $\mathbf{6 1 ( 7 7 . 2 2 \% )}$ & $\mathbf{1 8 ( 2 2 . 7 8 \% )}$ & $\mathbf{7 9 ( 1 0 0 \% )}$ \\
\hline
\end{tabular}

Source: Research Data, 2015

The views of key informants on the challenges that prevent MPs from adopting the principles of SLP were also analyzed using a graph as shown in Figure 8.

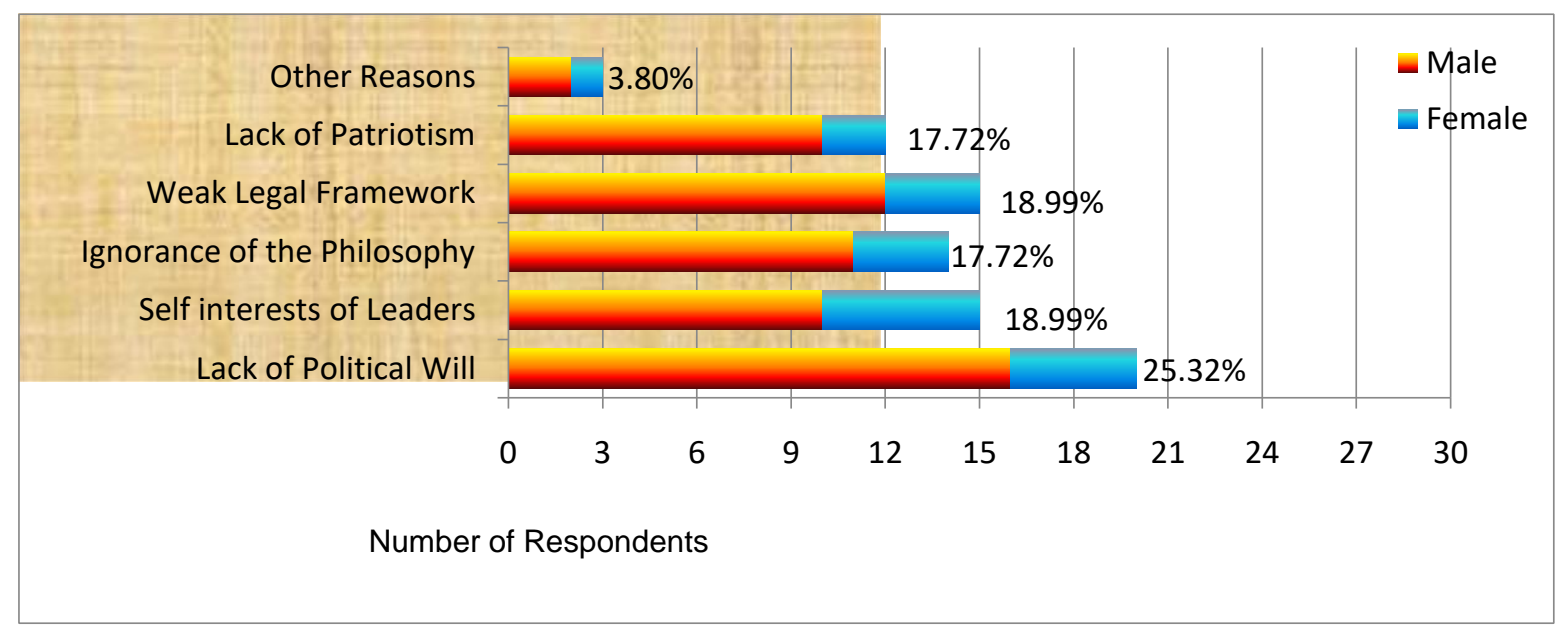

Figure 8. Detailed analysis of key informants' views on the challenges of adopting SLP Source: Research Data, 2015

The graph generally reveals that the lack of political will was the most leading challenge pointed out although there was no big range from the other four mentioned challenges 
excluding the 'other reasons' variable which had only $3(3.80 \%)$. In this regard, the distribution of key informants views were almost even indicating that the gravity of the mentioned challenges were considerably relevant and applicable.

Basing on the research findings obtained from the study, it can be concluded that there are challenges towards the adoption of the principles of SLP in the public leadership framework and particularly to MPs. The research findings revealed that $64(23.02 \%)$ out of $278(100 \%)$ respondents participated in the study had the views that 'lack of political will of leaders' seems to be the major challenge while $58(20.86 \%)$ mentioned 'self-interests of leaders' to be the challenge. Likewise, 54(19.42\%) respondents were of the views that 'the ignorance of the philosophy' was the challenge; 48(17.27\%) said 'weak legal framework to control conflict of interests of leaders' seems to be the major challenge and there was another cluster of $42(15.11 \%)$ respondents who pointed out that 'lack of patriotism of leaders' was the major challenge. However, there was a small group of respondents who indicated that there are more other reasons than the mentioned ones which restrain MPs from adopting the principles of SLP. The other reasons added by this cluster were poverty and corruption. Table 4.9 shows the general summary of responses from all respondents participated in the study.

Table 4.9. Summary of views of all respondents on the challenges of adopting SLP

\begin{tabular}{llrrr}
\hline Answer options: & \multicolumn{2}{c}{ No. of } & Total Respondents & Involved $(\mathrm{N}=278)$ \\
\cline { 3 - 5 } & MPs & Key Informants & RGPs & Total \\
\hline A: Ignorance of the Philosophy & $25(8.99 \%)$ & $14(5.04 \%)$ & $15(5.40 \%)$ & $54(19.42 \%)$ \\
B: Self-interests of Leaders & $22(7.91 \%)$ & $15(5.40 \%)$ & $21(7.55 \%)$ & $58(20.86 \%)$ \\
C: Lack of Political Will & $21(7.55 \%)$ & $20(7.19 \%)$ & $23(8.27 \%)$ & $64(23.02 \%)$ \\
D: Weak Legal framework to & & & & \\
control conflicts of interests & $19(6.83 \%)$ & $15(5.40 \%)$ & $14(5.04 \%)$ & $48(17.27 \%)$ \\
E: Lack of Patriotism of Leaders & $18(6.47 \%)$ & $12(4.32 \%)$ & $12(4.32 \%)$ & $42(15.11 \%)$ \\
F: Other reasons & $4(1.44 \%)$ & $3(1.08 \%)$ & $5(1.80 \%)$ & $12(4.32 \%)$ \\
\hline Total & $109(39.21 \%)$ & $79(28.42 \%)$ & $90(32.37 \%)$ & $278(100 \%)$ \\
\hline
\end{tabular}

Source: Research Data, 2015

The summary of views of all respondents on the challenges for MPs adopting the principles of servant-leadership in discharging their duties and responsibilities were also analyzed using a graph according to their categories as shown in Figure 9. The graph shows that the top three leading challenges were that of 'lack of political will' supported by 64(23.02\%) respondents, 'self-interests of leaders' supported by 58(20.86\%) and 'ignorance of the philosophy' supported by 54(19.42\%) respondents and in total being supported by 176(63.31\%) out of $278(100 \%)$ respondents participated in the study. 


\section{$\underline{\Lambda \text { Macrothink }}$}

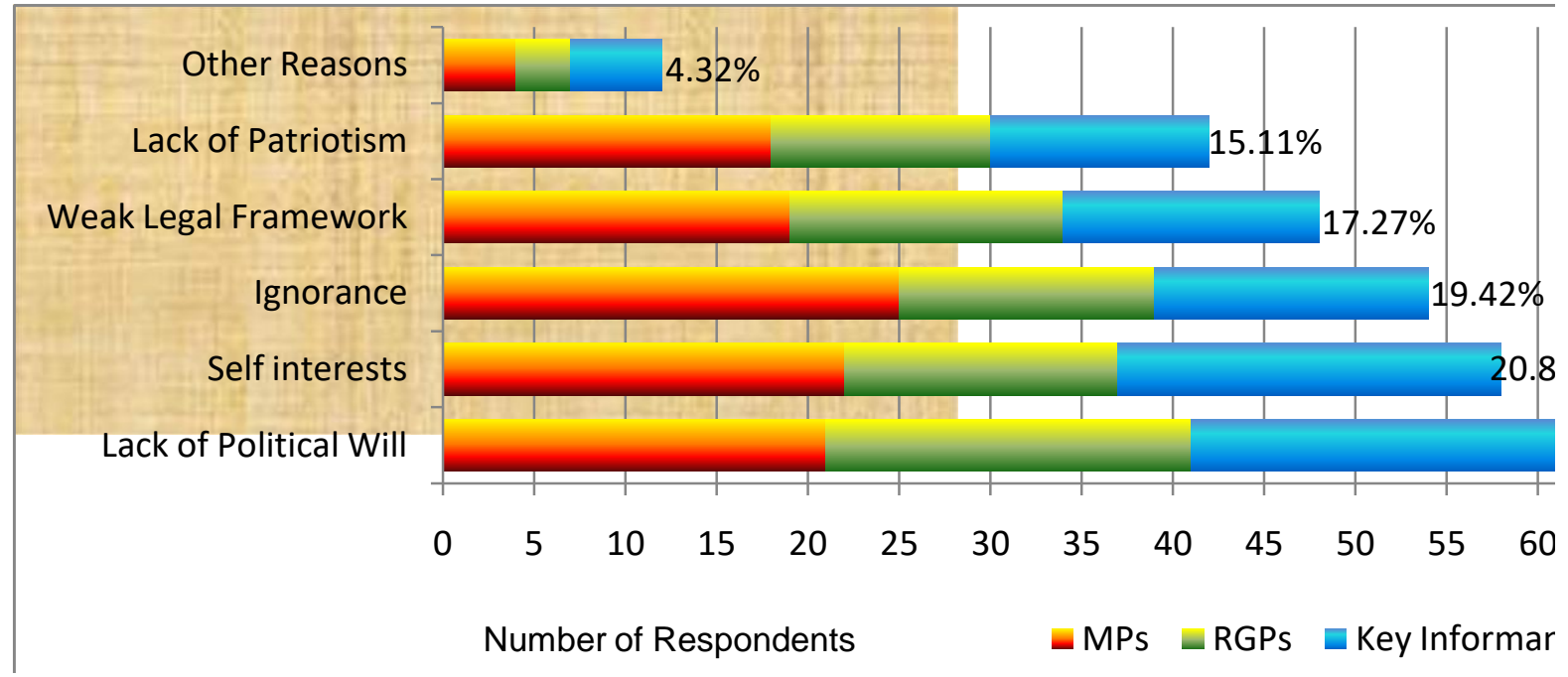

Figure 9. Summarized analysis of all respondents on challenges ofadopting SLP

Source: Research Data, 2015

\section{Conclusion and Recommendation}

The research findings have proved that there are many prospects of adopting servant leadership philosophy if Tanzania really needs to strengthen its public leadership. In the political realm, the adoption of fundamental principles of SLP will help, among other things, to groom political leaders who are ethical, patriotic and devoted to serve their followers; to give them skills of inculcating in their followers a sense of community and a spirit of holistic approach to work; to build a corrupt free and harmonious society; bring them closer to their voters and thus be able to enhance public trust and government confidence which are the most pleas of the public especially the poor to their public leaders.

Although the research findings proved that there are many prospects of adopting servant leadership philosophy in the public leadership, yet it is critically emphasized that servant leadership philosophy cannot stand alone as a discrete means of curbing leadership deficiencies in the public service. It is therefore recommended that in its future plans the government should think of enhancing its established ethics and code of conduct for its public leaders by adopting the principles of servant leadership philosophy. The government should also think of giving more powers and capacity to the Ethics Secretariat than it is now so that effective measures can be taken against public leaders especially leaders from the political realm who tend to breach the Public Leaders Code of Ethics Act of 1995 (and its subsequent amendments) and other established ideals thinking that they are not bound to them for most of them they have never being taken to task. If possible, the government should also think of reviewing the Public Leaders Code of Ethics Act of 1995 for there are still some lacunas to be addressed especially from Section 8 - 15 regarding the enforcement mechanism and declaration of assets and liabilities of public leaders; and also, in the area of declaration of interest of public leaders in dealing with government contracts. On ensuring sustainability, the government should also thinking of training public leaders on SLP and including SLP in school curricula topics with a view of grooming patriotic and ethical leaders of the next 
generation.

\section{Areas for Further Study}

Apart from being a source of reference to politicians, policy-makers and other stakeholders, this study is expected to inspire other academicians and researchers to conduct more related researches. This is because it is the first study to be conducted in Tanzania researching on servant leadership philosophy. It is therefore recommended that more researches have to be conducted with the aim of assessing the general impact and contribution of the servant-leadership philosophy on enhancing integrity, patriotism, ethics and moral standards to both public leaders and other public servants in Tanzania and beyond. This study is expected to fit much better in the public sector framework rather than private sector. This is because of its nature and type of data collected. It is therefore further recommended that more researches should be conducted to bridge the existing knowledge gap on whether the SLP has any prospects or not in changing the attitude of both leaders and employees towards their work in the private sector.

\section{References}

Abok, A. M. (2013). Factors Affecting Effective Implementation of Strategic Plans in Non-Governmental Organizations in Kenya, JKUAT-Nairobi: unpublished report.

Awino, Z. B. (2007). The Effect of Selected Variables on Corporate Performance: A Survey of Supply Chain Management in Large Private Manufacturing Firms in Kenya. Unpublished Thesis report, University of Nairobi.

Ayittey, G. B. N. (1992). Africa Betrayed. New York: A Cato Institute Book.

Barker, E. (1906). The Political Thought of Plato and Aristotle: New York.

Bell, R. H. (2002). Understanding African philosophy: A cross-cultural approach to classical and contemporary issues. New York: Routledge.

Creswell, J. W. (2009). Research Design: Qualitative, Quantitative and Mixed Methods Approaches. Sage Publications. London.

Dambe, M., \& Moorad, F. (2008). From Power to Empowerment: A Paradigm Shift in Leadership. South Africa Journal of Higher Education, 22(3), 575-587.

Dennis, R. S. (2004). Servant leadership theory: Development of the servant leadership assessment instrument. (Doctoral dissertation). Regent University, Virginia Beach, VA. (UMI 3133544).

Dewey, J. (1922). Human nature and conduct. Amherst MA: Promethus Books.

Enon, J. C. (1998). Educational Research, Statistics and Measurement, Unpublished Manual of Makerere University. Kampala.

Gakuru, O. (1998). Lean on me. Orbit, 68. Retrieved February 10, 2014, from http://www.oneworld.org/vso/pubs/orbit/68/volunt.htm 
Gasarasi, C. (2004). The General Environment in which the Members of Parliament Work. In Mukandala, R.S.et al (ed). People's Representatives: Theory and Practice of Parliamentary Democracy in Tanzania. Fountain Publishers Ltd. Kampala.

Graham, J. (1991). Servant-leadership in Organizations: Inspirational and Moral. Leadership Quarterly, 2(2), 105-119. https://doi.org/10.1016/1048-9843(91)90025-W

Greenleaf, R. K. (1970). The servant as a leader. Indianapolis, IN: Greenleaf Center.

Greenleaf, R. K. (1977). Servant-leadership: a journey into the nature of legitimate power and greatness. Nahwah, NJ: Paulist Press.

Greenleaf, R. K. (1996). On becoming a servant-leader. San Francisco: Josey-Bass Publishers.

Greenleaf, R. K. (1998). The power of servant-leadership. San Francisco, CA: Berrett-Koehler Publishers.

Hobbes, T. (1651). Leviathan or the Matter, Forme and Power of a Commonwealth Ecclesiasticall and Civil. London: Green Dragon St. Paul Church.

Kahl, J. (2004). Leading from the heart. Westlake, OH: Jack Kahl and Associates.

Kaufman (2008). A Book Review: Conflict of Interest and Public Life: Cros-National Pespectives by Christine Trost and Alison Gash (eds.) (Cambridge: Cambridge University Press).

Kneller, G. F. (1997). A method of enquiry. In J. Haton \& P.V. Ploufe (Eds.), Science and it ways of knowing (pp.11-25). Upper Saddle River, NJ: Prentice Hall.

Kosha, J. N. (2005). Servant leadership theory: Application of the construct of service in the context Kenyan leaders and managers. (Doctoral dissertation). Regent University, Virginia Beach, VA. (UMI 3188226).

Kothari, C. R. (2004). Research Methodology: Methods and Techniques, $2^{\text {nd }}$ Edition. India.

Laub, J. (2004). Defining Servant Leadership: A Recommended Typology for Servant Leadership Studies. Proceedings of the 2004 Servant Leadership Research Roundtable.http://www.regent.edu/acad/global/publications/sl_proceedings/home.shtml.

Lawrance, M., \& Spears, L. C. (2004). Practising servant-leadership: succeeding through trust, bravery, and forgiveness. San Francisco: Jossey-Bass.

Liviga, A. (2004). The Role of Members of Parliament as Representatives of the People". In Mukandala, R.S.et al (ed). People's Representatives: Theory and Practice of Parliamentary Democracy in Tanzania. Fountain Publishers Ltd. Kampala.

Mason, J. (2002). Qualitative researching (2nd ed.). Thousand Oaks, CA: Sage Publications.

Mbiti, J. (1969). African religions and philosophies. London, Heinemann.

McGee-Cooper, A., \& Trammell, D. (2013). The Essentials of Servant Leadership: Principles 
in Practice. Dallas: Texas.

Mugenda, O. M., \&Mugenda, A. G. (2003). Research Methods: Quantitative and Qualitative Approaches. Nairobi: Acts Press.

Nelson, L. (2003). An exploratory study of the application and acceptance of servant-leadership theory among black leaders in South Africa. Regent University: Digital Dissertations. (UMI No. 3086676).

Nyerere, J. K. (1968). Freedom and Socialism. Oxford University Press: Tanzania. Oxford English Dictionary. (1971). Oxford University Press.

Patterson, K. A. (2003). Servant leadership: A theoretical model. Dissertation Abstracts International (UMI No. 3082719).

Rickman, H. P. (2005). Understanding the Social Science, London: Heinemann.

Roussaeau, J. J. (1762). The Social Contract. The University of Adelaide: South Australia. 5005 .

Ruona, W., \& Lynham, S. (2004). Towards a philosophical framework for thought and practice. Human Resource Development International, 7(2), 151-164. https://doi.org/10.1080/13678860310001630665

Russell, R. F. (2001). The role of values in servant leadership. Leadership and Organization Development Journal, 22(2), 76-83. https://doi.org/10.1108/01437730110382631

Sekaran, U. (2003). Research Methods for Business, A Skill Building Approach. $4^{\text {th }}$ Edition, New Jersey: Haboken Publishers.

Sendjaya, S., \& Sarros, J. C. (2002). Servant leadership: Its origin, development and application in organizations. Journal of Leadership and Organizational Studies, 9(2), 57-65. https://doi.org/10.1177/107179190200900205

Spears, L. (1996). Reflections on Robert K. Greenleaf and servant-leadership. Leadership and Organization Development Journal, 17(7), 33-35. https://doi.org/10.1108/01437739610148367

Tenga, R. W. (2010). The Legal Framework for the Regulation of Public Ethics in Tanzania: A Paper Presented to the Workshop for Members of Parliament of the United Republic of Tanzania Organized by The Ethics Secretariat: April, 27.

The New International Version Bible. (1986). Concordia Self-Study Bible. St. Louis, MO: Concordia Publishing.

URT (1995). The Public Leadership Code of Ethics Act No.13 of 1995. Dar es Salaam: Government Printer. 


\section{Copyright Disclaimer}

Copyright for this article is retained by the author(s), with first publication rights granted to the journal.

This is an open-access article distributed under the terms and conditions of the Creative Commons Attribution license (http://creativecommons.org/licenses/by/4.0/). 